\title{
Some Misleading Terms
}

Ethnology-I use the word loosely, as the most common French equivalent for what has been called "Social Anthropology" in Britain and "Cultural Anthropology" in America. Its use shades into "ethnography" when designating empirical research. Although it is convenient to make the distinction between "ethnology" and "ethnography," I do not wish to imply that they are sharply dissimilar intellectual undertakings.

Canaque-An indiscriminate name applied by white settlers to native New Caledonians. In its English form, kanaka, it exists widely in the Pacific, usually with a disparaging connotation. However inaccurate and offensive the term may appear, I have not eliminated it from this study (1) because Leenhardt used it, without prejudice, throughout his life, (2) because its use is common in French ethnological circles to designate specifically the Melanesians of New Caledonia, (3) because it has been adopted as a term of national pride by Melanesians. I have left Canaque untranslated.

Pagan, Savage - Leenhardt commonly used paien neutrally to denote only pre- or non-Christian. He sometimes invested the pagan "stage" of moral development with the dignity of classical antiquity or that of the early Hebrews. The French sauvage is more ambiguous than the English "savage," for it implies "wild," "undomesticated," or "natural" (as in La Pensée Sauvage or "le camping sauvage"). "Pagan" and "savage" are not necessarily pejorative. 
